\title{
«... men ble stående ansikt til ansikt i time etter time»
}

\section{Norske NPN-konstruksjonar ${ }^{1}$}

\author{
Av Torodd Kinn
}

\begin{abstract}
Ein NPN-konstruksjon består av eit teljeleg substantiv i ubestemt eintal følgt av ein preposisjon følgd av det same substantivet $\mathrm{i}$ ubestemt eintal, som ansikt til ansikt og time etter time. Stundom har konstruksjonen modifiserande tillegg, som i kasse på kasse med flasker og vegg i vegg med badet. NPN-konstruksjonar har vore diskuterte ein del i seinare år, framfor alt basert på engelsk materiale, men knapt noko om norsk. Artikkelen går først inn på nokre moment frå tidlegare forsking og den analysen som blir lagd til grunn. Basert på eit stort materiale frå Leksikografisk bokmålskorpus blir det så unders $\varnothing \mathrm{kt}$ kva modifiserande (i hovudsak adverbiale) og nominale syntaktiske funksjonar NPN-konstruksjonar har i norsk. Vidare blir produktiviteten til konstruksjonar med ulike preposisjonar unders $\varnothing \mathrm{kt}$. Fokuset ligg på uttrykk med dei åtte preposisjonane etter, for, i, mot, om, på, til og ved. Nokre av preposisjonane førekjem nesten berre i adverbial, men andre er vanlege i nominale funksjonar òg. NPN-konstruksjonar med etter, på, for og til dels mot viser $\mathrm{h} \emptyset \mathrm{g}$ produktivitet, mens dei andre er lite produktive.
\end{abstract}

\section{Innleiing}

Uttrykk som ansikt til ansikt og time etter time har fătt ein del merksemd i forskinga dei siste åra, særleg i engelsk. Sentralt i litteraturen står Jackendoff (2008). Jackendoff nyttar termen NPN construction om dei nemnde uttrykka, og eg brukar termen NPN-konstruksjon på norsk, eller berre

1. Takk til fagfellane og redaksjonen for nyttige innspel som har hjelpt meg til å skrive ein betre tekst. Takk til Porsteinn Indriðason for hjelp med islandsken. 
NPN. Eg set termen i fleirtal for å omtale variantar med ulike preposisjonar. (1)-(4) inneheld døme i feit skrift.

(1) De kommer side ved side på grusveien $(\mathrm{LBK})^{2}$

(2) Jeg hørte Ellen dumpe ned trinn for trinn (LBK)

(3) I hylla på kontoret hans står perm på perm med faglitteratur og prosjektbeskrivelser (LBK)

(4) Et stort kjøpesenter ble oppført vegg i vegg med skolen (LBK)

Ein NPN kan definerast som følgjer: Det er éin syntaktisk konstituent som består av to identiske teljelege substantiv (N1 og N2) i ubestemt eintal med ein preposisjon (P) imellom. Substantiva kan ikkje ha tillegg av demonstrativ, possessiv eller kvantor - heller ikkje ubestemt artikkel; dei er altså «nakne» eintalsformer (jf. Borthen 2003). Fråvær av artikkel er uvanleg for teljelege substantiv i motsetnad til ikkje-teljelege, og det er dette særdraget ved NPN som er grunnen til at konstruksjonen er definert som avgrensa til dei teljelege substantiva. Andre modifiserande tillegg kan i nokon grad førekomme. På norsk er det i hovudsak tale om preposisjonsfrasar etter N2, som i (3) og (4). ${ }^{3}$ Ein interessant eigenskap er at NPN-ar både kan ha modifiserande funksjon (oftast adverbial), som i (1), (2) og (4), og nominal funksjon, t.d. som komplementet i preposisjonsfrasen i (3). Men avhengig av preposisjonen varierer det sterkt kor vanleg nominal funksjon er; modifiserande funksjon er det mest frekvente.

I Jackendoff (2008) blir grammatikken til engelske NPN-ar diskutert og framstilt som svært uregelmessig. Basert på norsk og dels islandsk empiri argumenterer Kinn (under utgiving) for at slike uttrykk er mindre spesielle enn Jackendoff og somme andre forskarar har hevda. Så langt eg har klart å finne ut, finst det elles inga forsking på desse uttrykksmåtane i norsk, men sjå òg Kinn (under vurdering). Eg kjenner heller ikkje til noko om dansk eller svensk.

Målet med artikkelen her er framfor alt å fylle forskingslakunen på tre punkt:

2. LBK = Leksikografisk bokmålskorpus. Sjå Knudsen \& Fjeld (2013).

3. På engelsk kan ein ha adjektiv framfor $\mathrm{N}_{2}$ og ev. $\mathrm{N}_{1}$, som i (rainy) day after rainy day; det er svært uvanleg i norsk. Dette ser ut til å variere ein del mellom språk, jf. Pskit (2015). Konstruksjonen i (3) med ein modifiserande PP på med er ein pseudopartitiv konstruksjon (sjå avsnitt 5). 
- Kva preposisjonar er brukte i norske NPN-konstruksjonar?

- I kva grad er NPN-konstruksjonane høvesvis modifiserande og nominale?

- Kor produktive er NPN-konstruksjonane?

Dette unders $\varnothing$ kjer eg ved å gjennomf $\varnothing$ re ein omfattande korpusstudie. Tilnærminga er bruksbasert (Barlow \& Kemmer 2000) og i vid forstand konstruksjonsgrammatisk (Hoffmann \& Trousdale 2013). Eg gjer bruk av teori om nake eintal (Borthen 2003) og omgrep frå kognitiv grammatikk (Langacker 1987, 1991).

I avsnitt 2 går eg kort inn på forskinga på NPN-konstruksjonar og analysen av to semantiske variantar: tvilling-NPN og kjede-NPN. I avsnitt 3 gjer eg greie for metode og materiale i den empiriske unders $\varnothing \mathrm{k}-$ inga. I avsnitt 4 gir eg eit oversyn over kva syntaktiske funksjonar NPN-ar kan ha på norsk, og eg diskuterer semantiske typar av adverbial. Avsnittet presenterer dessutan ein analyse av det grammatiske tilh $\varnothing$ vet mellom nominale og modifiserande NPN-ar. Avsnitt 5 analyserer to ulike former for NPN-intern modifisering. I avsnitt 6 tek eg for meg NPNkonstruksjonar med åtte frekvente preposisjonar (etter, for, $i$, mot, om, $p a ̊, t i l$ og ved), med eit tillegg om mindre brukte preposisjonar. Avsnitt 7 oppsummerer og konkluderer. ${ }^{4}$

\section{Teoretisk bakgrunn}

Bortsett frå det noko uvanlege i bruken av nake eintal av teljelege substantiv gir ein NPN inntrykk av å vere ein substantivfrase med N1 som kjerne. Sekvensen av $\mathrm{P}$ og N2 ser ut som ein preposisjonsfrase som modifiserer N1, der P er kjerne og N2 kjerne i ein substantivfrase som er komplement i preposisjonsfrasen. ${ }^{5}$ Syntaktisk er dette den same struk-

4. Kinn (under utgiving) handsamar nokre av dei norske NPN-konstruksjonane semantisk og syntaktisk for å utvikle den teoretiske analysen av NPN-konstruksjonar generelt (ikkje berre i norsk, men òg i andre språk med tilsvarande uttrykksmåtar). Artikkelen her legg dei analysane til grunn (avsnitt 2) og utviklar delar av dei vidare i større detalj (avsnitt 4.3 og 5). Kartlegginga av syntaktiske funksjonar og adverbialtypar går djupare her (avsnitt 4.1-2), og det same gjeld unders $\varnothing$ kinga av konstruksjonar med dei einskilde preposisjonane: betydning, vanleg førekommande substantiv, eksemplar-, type- og hapaxfrekvensar og produktivitet (avsnitt 6).

5. 'Kjerne' (= 'hovud'), 'modifiserar' og 'komplement' er semantisk definerte omgrep 


\section{TORODd KinN}

turen som ein har i eit «standard» uttrykk som pera i lampa. Semantisk står preposisjonen for ein relasjon, og N1 og N2 står for høvesvis primærdeltakar og sekundærdeltakar i relasjonen. ${ }^{6}$ I (4) er det t.d. ein 'heilt inntil'-relasjon mellom éin vegg og ein annan vegg uttrykt av preposisjonen $i$. Vi ser nærmare på dette i underavsnitta nedanfor.

Funksjonen til NPN-en i den overordna konstruksjonen (oftast ei setning eller ein verbfrase) er variabel; han kan ha modifiserande (typisk adverbial) eller nominal funksjon, slik (1)-(4) illustrerer. Analysen av dette kjem i avsnitt 4.3. Modifiserande tillegg i NPN-en, som i (3) og (4), er av ulike slag som vi skal sjå kort på i avsnitt 5.

\subsection{Jackendoff (2008) og andre bidrag}

Som nemnt er Jackendoff (2008) om engelske NPN-ar det viktigaste forskingsbidraget så langt. Engelsk står òg i sentrum i Travis (2001, 2003), Lindquist \& Levin (2003), Matsuyama (2004), Boberg (2009), Pskit (2012, 2015 (òg om polsk), 2017) og Haïk (2013). Nederlandske uttrykk er tema i Poß (2007, 2010) og tyske i Ziem (2018). Roch, Keßelmeier \& Müller (2010) tek for seg tysk og engelsk, og dessutan fransk og spansk. Kinn (under utgiving) er basert på norsk og islandsk og Kinn (under vurdering) på norsk. Noko på sida av dei andre studiane står dei formalsemantisk orienterte av Beck \& von Stechow (2003, 2005).

Skildringa først i avsnitt 2 er den analysen som Kinn (under utgiving) argumenterer for, i motsetning framfor alt til Jackendoff (2008). Jackendoff argumenterer for at NPN er ein konstruksjon som ikkje følgjer vanleg frasestruktur eller har komposisjonell oppbygging. Denne synsmåten har tilsynelatande hovudsakleg bakgrunn i ein idé om at nake eintal normalt ikkje fungerer som argument i språk som har artiklar (jf. engelsk Jill threw a/the ball over the fence, men *Jill threw ball over the fence). Om ein legg til grunn ei slik forståing, kan ikkje $\mathrm{N} 1$ vere (ein normal) kjerne i NPN, og N2 kan ikkje vere (eit normalt) komplement til P; sjå nærmare i Kinn (under utgiving).

Andre syntaktisk orienterte bidrag har argumentert for analysar som på ulike måtar tillegg NPN-konstruksjonane ein idiosynkratisk struktur.

(jf. Langacker 1987: 324-327). Skildringa som er gitt her, er dermed ikkje reint syntaktisk, men òg semantisk, i tråd med tanken om at alle grammatiske konstruksjonar har både uttrykk og innhald.

6. Primerdeltakar og sekunderdeltakar er dei norske termane for trajector og landmark. 
Haïk (2013) vil analysere somme NPN-ar som sideordningsstrukturar (med P som konjunksjon). Travis (2001, 2003) og delvis Jackendoff (2008) reknar med at det er syntaktisk reduplikasjon som gir to identiske substantiv. Travis analyserer dessutan P som kvantor. Kinn (under utgiving) drøftar desse framlegga og legg fram ein alternativ analyse der NPN-ane visseleg har ein del særtrekk, men er mindre avvikande enn det Jackendoff, Travis og Haïk hevdar.

\subsection{Nake eintal, typar og instansar}

Borthen (2003) viser at det finst ei rekkje norske konstruksjonar der nake eintal har argumentfunksjon. Det er t.d. uttrykksmåtar som i Hun går på skole, Hun hadde rød ytterfrakk, et bord med bvit duk, Buss er et naturvennlig kjøretøy og Jeg vil anbefale telt (jf. Rosén og Borthen 2017). Eg legg til døme som desse: gleden ved å legge maske til maske; en sport der mann møter mann; Så lenge slekt følger slekt. Sjå elles Stvan (2007) og de Swart $\&$ Zwarts (2007) for engelsk. Nake eintal har særlege semantiske eigenskapar (sjå nedanfor), men kan altså godt ha argumentfunksjon, i både norsk og engelsk. Fleire av grunnane til å sjå på NPN-konstruksjonane som heilt uregelmessige fell dermed vekk. N1 kan vere kjerne i NPN, og N2 kan vere kjerne i komplementet til preposisjonen.

Kinn (under utgiving) byggjer vidare på teori frå Borthen (2003) og Langacker $(1987,1991)$. Borthen legg til grunn for sine analysar at ubestemte substantivfrasar har to semantiske nivå. Dei tilfører diskursen både ein eksemplardiskursreferent og ein typediskursreferent, og vi kan med ulike uttrykksmåtar legge fokuset på typen eller eksemplaret. Nake eintal tenderer mot å fokusere på typen, mens substantiv med artikkel tenderer mot å fokusere på eksemplaret. Omgrepa til Borthen har mykje til felles med Langacker sitt skilje mellom (nominal) type og instans. Profilen til ei naken eintalsform er ein type. ${ }^{7}$ Når ein legg til artikkel, blir ein instans av typen profilert. La oss sjå på korleis dette artar seg i praksis.

Om vi seier Hun spiste med gaffel eller Hun spiste med en gaffel, kan vi godt snakke om den same situasjonen. Brukar vi nake eintal (gaffel), legg vi vekt på reiskapstypen og dermed ein måte å få i seg maten på. Borthen vil seie at gaffel her har fokus på ein typediskursreferent, og Langacker

7. Profilen er det elementet i betydninga til eit språkleg uttrykk som er framheva som det sentrale (som figuren på ein bakgrunn). 


\section{TORODd KinN}

vil seie at det profilerer typen 'gaffel'. Legg vi til ubestemt artikkel (en gaffel), dreiar vi merksemda mot eit spesifikt tilfelle av reiskapstypen. Borthen vil seie at en gaffel har fokus på ein eksemplardiskursreferent, og Langacker vil seie at det profilerer ein instans av typen 'gaffel'.

Den semantiske forskjellen mellom gaffel og en gaffel er illustrert i figur 1. Profilen til gaffel (vist med tjukk linje) ligg på typeplanet (TP) og er foreinleg med at det kan vere snakk om fleire instansar på instansieringsplanet (IP). Men ved en gaffel er profilen knytt til éin spesifikk instans på instansieringsplanet. ${ }^{8}$ (Det er vist tre instansar, men det talet er arbitrært.)
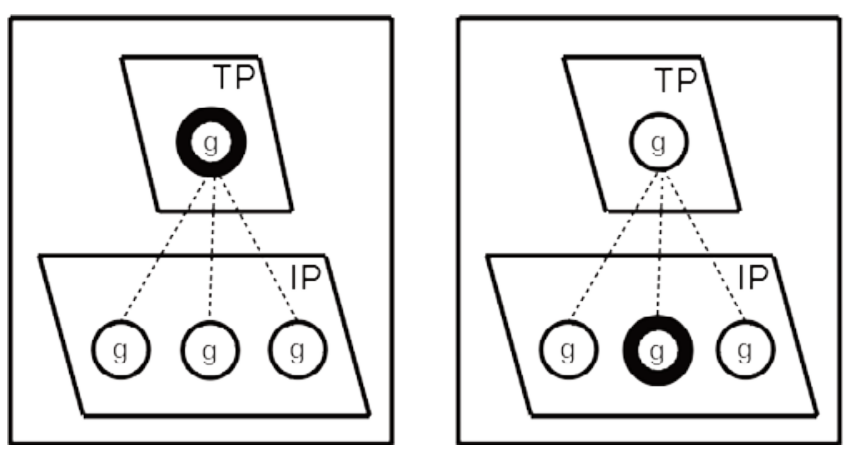

Figur 1. Betydningane til gaffel (til venstre) og en gaffel (til høgre)

Skilnaden mellom gaffel og en gaffel er subtil. Men han fører m.a. med seg at det er mindre overraskande om 'ho' brukte fleire ulike gaflar om ein seier berre gaffel, enn om ein seier en gaffel; typen er viktigare enn instansen. Det kan vere fleire gaflar inne i bildet, men i så fall vil det normalt vere fleire delsituasjonar etter kvarandre med éin gaffel i kvar som ein kan generalisere over, slik at det framleis er motivert å bruke gaffel i eintal. Dersom fleire gaflar er i bruk samtidig, vil ein nok heller seie f.eks. Hun spiste med to gafler.

I Hun spiste med gaffel kan kanskje forskjellen mellom type og instans verke mindre viktig. Men i De spiste med gaffel trer han klarare fram. Sidan subjektsreferenten 'dei' er fleire personar, er det rimeleg å anta at

8. Dette hindrar ikkje at eintalsbetydninga kan inngå i konstruksjonar som i Jeg ga hver av dem en gaffel, der en gaffel kjem innanfor rekkjevidda til kvantoren bver og det dermed er tale om fleire gaflar. 
dei brukte kvar sin gaffel. Personane vil på instansieringsplanet bli knytte til kvar sin 'gaffel'-instans. Typeprofilen til nake eintal gaffel er uttrykk for ei generalisering over delsituasjonar med éin gaffel kvar.

NPN-konstruksjonar inneheld per definisjon to identiske nakne eintalssubstantiv. Substantiva viser til den same nominale typen (med eintalsbetydning). I figurane nedanfor er typen derfor representert to gonger. Kvar typeførekomst svarar til éin eller fleire instansar. ${ }^{9} \mathrm{Vi}$ skal sjå på korleis dette artar seg for to semantiske hovudtypar av NPN.

\subsection{Tvilling-NPN}

Mann mot mann er eit døme på den første hovudtypen: tvilling-NPN. Den semantiske strukturen er illustrert i figur 2. (Figuren viser den nominale grunnstrukturen. Strukturen i modifiserande NPN-ar blir diskutert i avsnitt 4.3.) Når ein brukar mann mot mann, viser begge dei nakne substantiva til typen 'mann'. Dei to typeførekomstane er representerte i typeplanet som $m \alpha$ og $m \beta$. Dei er knytte saman av ein 'mot'relasjon: $m \alpha$ er mot $m \beta$. Den tjukke pila viser retninga i relasjonen, frå primærdeltakar (d1) til sekundærdeltakar (d2). Relasjonen 'mot' tenderer dessutan til å vere resiprok, og derfor er $\mathrm{m} \beta$ òg mot $\mathrm{m} \alpha$, med omsnudde deltakarroller. ${ }^{10}$ Dette er representert med den tynne pila.

Kvar typef $\varnothing$ rekomst svarar til éin eller fleire instansar, som ikkje er profilerte. (5) og (6) viser uttrykk som blir tolka slik at det er høvesvis éin og fleire instansar per typeførekomst.

(5) Sogningen og fjordingen sloss mann mot mann

(6) Sogningene og fjordingene sloss mann mot mann

I (5) er det nærliggande å tolke situasjonen slik at det er dei to personane i subjektsreferenten som slåst mot kvarandre. Kvar typeførekomst svarar då til éin instans. I (6) er det minst fire personar i subjektsreferenten, og då vil kvar typeførekomst svare til fleire instansar (tre par er viste). ${ }^{11}$

9. Førekomst skal her forståast i høve til den semantiske representasjonen. Det er tale om éin type, men han er vist til to gonger og derfor representert med to førekomstar. Dette er ikkje noko spesielt for NPN-ar, men gjeld alltid når eit substantiv er nytta to gonger, som i Den gamle mannen hjalp den unge mannen.

10. Termen resiprok må ikkje tolkast formallogisk her. Det er tale om at ein i eit gitt tilfelle har den same relasjonen begge vegar mellom to deltakarar.

11. I konferanseinnlegg har eg omtalt typane og instansane i NPN-konstruksjonar som 


\section{ToROdD KinN}

Ein reell kampsituasjon vil neppe vere heilt velordna, men konseptualiseringa som det språklege uttrykket framstiller, er slik at mennene utgjer ordna par: $\mathrm{m} 1 \mathrm{mot} \mathrm{m} 2, \mathrm{~m} 3$ mot m4, $\mathrm{m} 5$ mot $\mathrm{m} 6$ osv. Dette er det normale ved preposisjonar; dei dannar ordna par av deltakarar.

Her har vi altså normalt ein resiprok relasjon: Ikkje berre er m1 mot $\mathrm{m} 2$, men $\mathrm{m} 2$ er òg mot m1, og tilsvarande for dei andre para. Av det at deltakarane i eit tvillingpar er vende mot kvarandre, følgjer det at dei er vende vekk frå dei andre para. ${ }^{12}$ Det er dette som skil ein tvilling-NPN som mann mot mann frå ein kjede-NPN som natt etter natt.

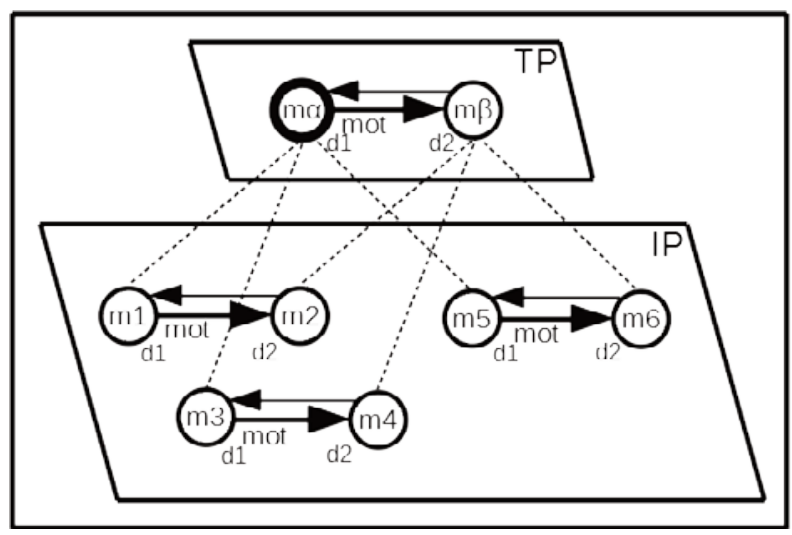

Figur 2. Den semantiske strukturen til den nominale grunnstammen i ein tvilling-NPN: mann mot mann

høvesvis virtuelle og manifeste referentar, jf. Langacker (1999, 2005). (Manifest er mitt framlegg til norsk term for engelsk actual i denne samanhengen; aktuell fungerer heller dårleg.) Typane er rett nok alltid virtuelle referentar. Men instansane kan vere både virtuelle og manifeste. I (5) og (6) er 'mann'-instansane manifeste. Men i andre kontekstar kan ein få «virtualisering» av referentar som dette. Til d $\varnothing$ mes vil det vere tilfellet i Når sogninger og fjordinger slåss mann mot mann, går det hardt for seg, der 'mann'-instansane er virtuelle. Virtuell referanse spelar ei viktig rolle i ei rekkje konstruksjonar, ikkje berre semantisk, men òg formelt, t.d. for adjektivsamsvar på predikativ i såkalla pannekakesetningar (jf. Haugen og Enger 2019).

12. I konferanseinnlegg har eg brukt termen par-NPN for 'tvilling-NPN', men den er litt uheldig sidan det òg er tale om ordna par i den andre hovudtypen, kjede-NPN. Som diskutert i Kinn (under utgiving) er det ikkje opplagt at alle NPN-ar fell inn under éin av dei to hovudtypane. Det kan vere at somme NPN-ar verken oppviser resiproke relasjonar som i tvilling-NPN eller kjedeordning som i kjede-NPN. Eg går ikkje nærmare inn på dette spørsmålet her. 


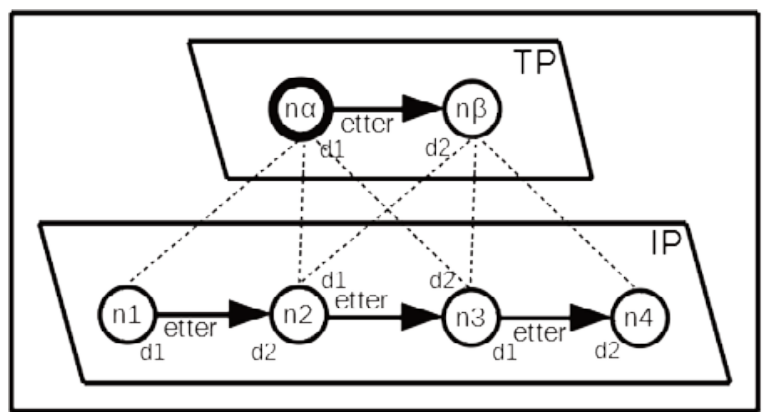

Figur 3. Den semantiske strukturen til den nominale grunnstammen i ein kjede-NPN: natt etter natt

\subsection{Kjede-NPN}

Den andre hovudtypen av NPN-ar er kalla kjede-NPN. Figur 3 syner den semantiske strukturen til kjede-NPN-en natt etter natt. I (7) kan ein rekne med at dei nakne eintalssubstantiva begge viser til typen 'natt', representert med n $\alpha$ og $n \beta$ på typeplanet i figuren. Her òg fører preposisjonssemantikken til at deltakarane opptrer i ordna par. Men betydninga til etter er slik at det ikkje kan oppstå nokon resiprok relasjon: Dersom $n \alpha$ er etter $n \beta$, kan ikkje $n \beta$ vere etter n $\alpha$. Dette blir tilsvarande på instansieringsplanet.

(7) Han hylte seg gjennom natt etter natt (forum.kvinneguiden.no)

Når ein brukar natt etter natt, vil det vere snakk om fleire enn to netter. Typeplanet med to nattførekomstar svarar til eit instansieringsplan der situasjonen med natt som følgjer natt, er replisert ubestemt mange gonger (igjen er tre viste i figuren). Men her skil kjede-NPN seg frå tvillingNPN. I ein tvilling-NPN er alle instansane ulike; det er ikkje overlapping mellom primær- og sekundærdeltakarar. Det følgjer av den resiproke ordninga. I ein kjede-NPN er ikkje sekundærdeltakaren vend mot primærdeltakaren, men står fritt til å sjølv opptre òg som primærdeltakar overfor ein ny sekundærdeltakar. På den måten blir altså sekundærdeltakaren i eitt ordna par eksemplaridentisk med primærdeltakaren i det neste. I ein tvilling-NPN har ein eitt eller fleire par av instansar som er orienterte parvis mot kvarandre. I ein kjede-NPN går orienteringa berre éin veg, og det oppstår ein serie av instansar som bortsett frå ordninga 


\section{ToRodd KinN}

har mykje til felles med fleirtalsbetydning: Han hylte seg gjennom natt etter natt betyr om lag det same som Han bylte seg gjennom flere netter etter hverandre. Kinn (under utgiving) argumenterer for at kjedeordning og fleirtalsliknande betydning motiverer at kjede-NPN mykje oftare enn tvilling-NPN førekjem i nominale funksjonar.

\section{Metode og materiale}

Metoden i unders $\varnothing$ kinga her kan delast i fire hovuddelar: (a) søking og første utsortering av feiltreff, (b) andre utsortering av feiltreff, (c) syntaktisk (og semantisk) klassifikasjon, (d) utarbeiding av deskriptiv statistikk.

\subsection{Søking og første utsortering av feiltreff}

Materialet for unders $\varnothing$ kinga blei samla inn med 29 s $\varnothing \mathrm{k}$ i Leksikografisk bokmålskorpus (Knudsen \& Fjeld 2013), eitt s $\varnothing \mathrm{k}$ for kvar bokstav i alfabetet. ${ }^{13}$ Det første søket henta ut treff på eit substantiv på $a$-i ubestemt form eintal direkte følgt av ein preposisjon direkte følgd av eit substantiv på $a$ - i ubestemt form eintal. Neste s $\varnothing \mathrm{k}$ gjaldt substantiv på $b$-, osv.

Resultata inneheldt òg treff der substantiva var ulike. Til d $\varnothing$ mes hadde a-materialet treff som anlegg for aking og advarsel fra avdelingsdirektør $\mathrm{i}$ tillegg til NPN-ar som ansikt til ansikt. Slike treff blei sorterte ut.

\subsection{Andre utsortering av feiltreff og problemtilfelle}

Etter den første utsorteringa var det i overkant av 14250 treff der substantiva var like. Vi kan kalle dette for NPN-sekvensar. I artikkelen her er NPN-konstruksjonen avgrensa strengt (jf. avsnitt 1). ${ }^{14}$ Det blei utelukka forholdsvis mange NPN-sekvensar som ikkje er NPN-ar ifølgje definisjonen:

13. Eg brukte korpuset over denne adressa: https://www.hf.uio.no/iln/tjenester/kunnskap/sprak/korpus/skriftsprakskorpus/lbk. Det kan òg brukast på Korpuskel: https://clarino.uib.no/korpuskel.

14. I tillegg til dei utelukka uttrykkstypane som er lista opp nedanfor, finst det ein del andre uttrykksmåtar som er i slekt med NPN-ane utan å falle inn under definisjonen her. Eg nemner én etter én, én for én, én til én, én mot én, to mot to (osv.), millioner på millioner (o.1.), litt etter litt, tett i tett, blått i blått (o.1.), og det finst nok nokre fleire. 
- inkjekjønnssubstantiv i fleirtal: Det var ikkje mange tilfelle av dette, men eg vurderte t.d. substantiva i $r \not r$ i $r \varnothing r$ (ein røyrleggingsmetode) til å vere fleirtal og ikkje eintal. Distinksjonen er somme gonger vanskeleg å trekkje.

- ikkje-teljelege substantiv: Dette var det ein del av, t.d. metall mot metall. Grunnen til avgrensinga er at ikkje-teljelege substantiv typisk er brukte utan ubestemt artikkel (Jeg leste litteratur, *?Jeg leste en litteratur) slik at det ikkje er noko spesielt $i$ at dei er nakne, i motsetning til teljelege substantiv (Jeg leste en artikkel, ?Jeg leste artikkel). Det er ikkje alltid enkelt å skilje mellom teljeleg og ikkje-teljeleg (jf. Rosén og Borthen 2017: 238).

- forledd i samansettingar: Dette har ein t.d. i munn-til-munn-metode, men slike uttrykk kom med i søket berre dersom det ikkje var brukt bindestrekar. Forleddet er rett nok ein NPN, men eg valde å halde orddanning utanfor unders $\varnothing$ kinga.

- ikkje-konstituentar: Dette har ein t.d. i tollbestemmelser som skilte provins fra provins, der NPN-sekvensen er eit objekt følgt av eit adverbial. Identiske NPN-sekvensar kan vere NPN-ar i nokre tilfelle og ikkje i andre. For eksempel har vi ein NPN i De kjemper mann mot mann (éin konstituent), men ikkje i Der kjemper mann mot mann (subjekt og adverbial). Jamfør omskriving til hjelpeverbskonstruksjon: De har kjempa mann mot mann (ikkje * De har mann kjempa mot mann) vs. Der har mann kjempa mot mann (knapt *? Der har kjempa mann mot mann).

- avvikande preposisjonsrelasjon og konstituens: Dette gjeld framfor alt fra $N$ til N-konstruksjonen, som i Soldatene går fra bus til bus. Det var over 4500 treff på denne konstruksjonen. Han skil seg både semantisk og syntaktisk frå NPN. I ein NPN står preposisjonen for ein relasjon mellom deltakarar som er viste til med $\mathrm{N}_{1}$ og N2. I fra $N$ til $N$ står fra og til for kvar sin relasjon mellom den same eksterne primærdeltakaren og betydningane til høvesvis N1 og N2 som sekundærdeltakarar. Soldatane rører seg frå hus 1 til hus 2; hus 1 rører seg ikkje. Syntaktisk er fra $N$ til $N$ to PP-ar i éin konstruksjon: $\left[\left[_{\mathrm{PP}} \mathrm{P}\left[{ }_{\mathrm{NP}} \mathrm{N}\right]\right]\left[_{\mathrm{PP}} \mathrm{P}\left[{ }_{\mathrm{NP}} \mathrm{N}\right]\right]\right]$ (liksom fra Oslo til Bergen i Fra Oslo til Bergen er det omtrent 46 mil, der til Bergen ikkje er underordna Oslo).

- bibelske repetisjonar: Eg utelukka $N$ for $N$-uttrykk av typen $\varnothing y e$ for $\varnothing y e$, der så å seie alle er frå bibeltekst eller er bibelske allusjonar. Nokre eksemplar er NPN-ar og kunne ha vore med som ein eigen semantisk variant av $N$ for $N$. Men dei er tekstleg svært avvikande, med passasjar som dette dømet (alt i same periode!): liv for liv, øye for øye, tann for tann, hånd for bånd, brent for brent, flenge for flenge, skramme for skramme. Ein hovudgrunn til utelukkinga var store vanskar med å avgjere om det dreidde seg om NPN-ar eller berre NPN-sekvensar. 


\section{TORODd Kinn}

- eit namn: Eg utelukka ein god del treff på namnet Beat for beat (eit fjernsynsprogram).

Eg sat att med 9241 NPN-eksemplar fordelte på 1206 typar. Åtte preposisjonar (etter, for, $i$, mot, om, på, til, ved) dominerer og står for 9210 NPN-eksemplar fordelte på 1182 typar (sjå avsnitt 6).

\subsection{Syntaktisk (og semantisk) klassifikasjon}

NPN-ar er som nemnt brukte både modifiserande og nominalt. Nominal bruk er likevel uvanleg ved somme preposisjonar. For å kartlegge dette sorterte eg NPN-ane i to syntaktiske kategoriar: modifiserande og nominal bruk. Modifiserande bruk er først og fremst ulike slags adverbial, men òg t.d. tillegg til substantiv (slåssing mann mot mann). Nominal bruk er i hovudsak subjekt, potensielt subjekt, objekt, komplement til preposisjon og predikativ. Eg skilde òg mellom ulike semantiske adverbialtypar, men måtte konkludere med at materialet bydde på så mange problemtilfelle at eg ikkje vil talfeste resultata på det punktet.

Temmeleg mange NPN-ar var det umogleg eller svært vanskeleg å kategorisere syntaktisk. Det gjeld overskrifter (ikkje del av nokon overordna konstruksjon) og døme frå tekst med fragmentarisk syntaks, som i (8):

(8) Enn så lenge er jeg sammen med de andre. Forenkler. Gjør det viktigste tydelig. Alt handler om det. Redusere systemene. Diagnosebildene. Dag for dag. Jeg gjør som historikeren og forkaster meningsløse budskap etter hvert som de strømmer på. (LBK)

Dag for dag i (8) er kanskje eit tidsadverbial. Men det er tvilsamt om det er rett å tildele det nokon syntaktisk funksjon når det står åleine mellom to punktum og tilknytinga til ein overordna verbal struktur dessutan er så uklar.

\subsection{Deskriptiv statistikk: frekvensar og produktivitet}

Trass i mange problemtilfelle gir materialet eit godt grunnlag for å seie noko om frekvensen og produktiviteten til NPN-konstruksjonane. Produktivitet er ikkje noko eintydig omgrep (jf. Bauer 2001), men tre frekvensmål er tilstrekkelege for formålet her:

- eksemplarfrekvens: Kor mange døme er det på NPN-ar med ein gitt preposisjon? 
- typefrekvens: Kor mange substantiv fordeler eksemplara seg på?

- hapaxfrekvens: Kor mange typar førekjem berre éin gong?

Høg typefrekvens er eitt teikn på produktivitet; det har blitt laga NPNar med mange ulike substantiv. $\mathrm{H} \varnothing \mathrm{g}$ hapaxfrekvens er eit anna teikn; at mange NPN-typar berre er brukte éin gong i materialet, tyder på at det er lett å lage nye typar. Eit enkelt produktivitetsmål får ein ved å dividere hapaxfrekvensen på eksemplarfrekvensen. Kombinerer ein dette målet med typefrekvensen, får ein eit nokså godt bilde av kor produktiv ein gitt konstruksjon er.

\section{Syntaktiske funksjonar}

Norske NPN-konstruksjonar førekjem i både modifiserande og nominale funksjonar. Her skal vi først sjå på modifiserande bruk og deretter på nominal bruk.

\subsection{Modifiserande NPN-ar}

De fleste modifiserande NPN-ane er adverbial. Som nemnt er semantisk kategorisering ofte vanskeleg, men norske adverbiale NPN-ar ser ut til a fordele seg over tre hovudtypar av semantiske roller: måte, tid og lengde.

Tvilling-NPN-ar er semantisk meir einsarta enn kjede-NPN-ar. Dei er gjennomgåande måtesadverbial som handlar om korleis deltakarane er posisjonerte i forhold til kvarandre, som i (9) og (10):

(9) og man treffer personen ansikt til ansikt i stedet for gjennom pc'en (LBK)

(10) Vi sovnet rygg mot rygg under åpen himmel (LBK)

Mange kjede-NPN-ar kan likeins karakteriserast som måtesadverbial. Slike måtesadverbial viser til éi eller anna form for fordeling. Fordelinga er prinsipielt av to hovudtypar. For det første kan det vere ein deltakar (vist til utanfor NPN-en) som er (del)samansett av fordelingseiningane (viste til med NPN-en). Dette har vi døme på i (11), der synderegisteret består av punkta som opplesinga er fordelt over. 


\section{ToRodd KinN}

(11) Uriel leste opp mitt synderegister punkt for punkt (LBK)

(12) Funnene vil bli presentert kommune for kommune (LBK)

For det andre kan det vere slik at det ikkje er nemnt nokon NPN-ekstern deltakar som svarar til fordelingseiningane. Det har vi døme på i (12), der verken funna eller presenteringa består av kommunar. ${ }^{15}$

Adverbial for utstrekning er vanlege, særleg utstrekning i tid (13), men òg fysisk utstrekning (14). Substantiva i slike NPN-ar denoterer normalt tids- og lengdeeiningar. Gang på gang fungerer som adverbial for frekvens, som i (15).

(13) folk vender tilbake år etter år for å gjøre en innsats (LBK)

(14) men [strømmen] går ... uhindret gjennom kabelen kilometer etter kilometer (LBK)

(15) Gang på gang så han seg tilbake (LBK)

Ein modifiserande NPN som er semantisk tilknytt komplementet i ein preposisjonsfrase, har vi i (16), mens (17) og (18) gir døme på modifiserande tillegg til substantiv.

(16) å befinne seg i en kjøttforretning med slakteriet vegg i vegg (LBK)

(17) Samtidig fortsatte de desperate kampene mann mot mann med uforminsket styrke (LBK)

(18) Styring av arrangementene dag for dag vil ... skje ved hjelp av et digitalt kart (LBK)

\subsection{Nominale NPN-ar}

Nominale NPN-konstruksjonar får ei semantisk rolle frå kjernen i den overordna konstruksjonen i kraft av å ha ein syntaktisk funksjon. Oftast er den overordna kjernen eit verb (i ei setning eller ein verbfrase) eller ein preposisjon (i ein preposisjonsfrase). NPN-ar kan ha dei vanlege nominale funksjonane. Dette er illustrert i d $\varnothing$ ma nedanfor, med subjekt i (19) -(20), potensielt subjekt i (21)-(22), objekt i (23) -(24), komplement til preposisjon i (25)-(26) og subjektspredikativ i (27)-(28).

15. Det kan ev. innvendast at funna mest truleg gjeld kommunar, men dette må reknast som noko ein kan slutte seg til pragmatisk, heller enn at det er ein del av semantikken til setninga. 
(19) Hakeslepp på hakeslepp følger under seansen (LBK)

(20) Langsomt blir vogn etter vogn trukket løs (LBK)

(21) i innboksen popper det fram linje etter linje med feite bokstaver (LBK)

(22) der det var gate etter gate med bare butikker (LBK)

(23) Plagg for plagg hadde Anna bretta sammen og lagt på plass (LBK)

(24) mens jeg har fylt kasse på kasse med jord (LBK)

(25) Kongen og dronningen har i år etter år svart på spørsmål (LBK)

(26) en av de ... som lar dagene skli forbi over halvliter på halvliter på den lokale bula på senteret (LBK)

(27) For Singer var et bibliotek lag på lag av avleiret materiale (LBK)

(28) men det blir bare påstand mot påstand (LBK)

Når ein NPN med ein preposisjon som typisk ikkje opptrer i nominale ledd, likevel gjer det, er det ofte metonymi og komprimert uttrykksmåte inne i bildet. Objektet i (29) er eit d $\varnothing$ me. $N$ til $N$ opptrer sjeldan nominalt, men her kan «avviket» forklarast med at munn til munn står metonymisk for 'munn-til-munn-metoden'.

(29) Prøvde å få liv i ham med munn til munn (LBK)

\subsection{Tilhøvet mellom nominal og modifiserande NPN}

Uttrykksmessig er ein NPN-konstruksjon grunnleggande ein substantivfrase. Men i løpande tekst fungerer dei fleste NPN-ar som adverbial, og nokre har andre modifiserande funksjonar. Av dei eksemplara som eg har klassifisert under ein syntaktisk funksjon, er 79,7 \% modifiserande, mens $20,3 \%$ er nominale (jf. avsnitt 6-7). I språkbruken er altså det store fleirtalet av NPN-ar modifiserande substantivfrasar, og meir spesifikt adverbial. Ein kan samanlikne NPN-en time etter time i Jeg sykla time etter time med ein meir velkjend type adverbial substantivfrase som flere timer i Jeg sykla flere timer, jf. Kinn (under utgiving).

Når ein substantivfrase utan noko uttrykk som viser adverbial funksjon, likevel opptrer som adverbial, har ein å gjere med ein implisitt relasjon mellom betydninga til den overordna konstruksjonen (oftast ei setning eller ein verbfrase) og den nominale betydninga til substantivfrasen. Slike relasjonar er typisk uttrykte av preposisjonar i norsk. Derfor kan oppbygginga av ei setning med adverbial NPN med fordel forståast på bakgrunn av ei tilsvarande setning der den einaste skilnaden er at NPN-en er innføydd som komplement i ein adverbial preposisjonsfrase. Vi kan ta utgangspunkt i Jeg sykla i time etter time (med $i$ ) for å nærme oss 


\section{TORODd KinN}

ein analyse av Vi sykla time etter time (utan $i$ ). Det er òg nyttig å ha eit blikk på det nærskylde språket islandsk, der substantiva er kasusbøygde.

I Jeg sykla i time etter time kan preposisjonen $i$ seiast å uttrykkje ein relasjon mellom aktiviteten 'eg sykla' og eit tidsrom der aktiviteten finn stad, 'time etter time'. Men temporal semantikk er langt ifrå den typiske betydninga til $i$; det er éin av fleire variantar og står til d $\varnothing$ mes som punkt 6 i Bokmålsordboka (s.v. $i$ II). Kva preposisjonen betyr her, kan ein berre slutte seg til på bakgrunn av eit innfløkt samspel mellom uttrykka for aktivitet ('eg sykla'), tidsrom ('time etter time') og dei ulike betydningane til preposisjonen, der den temporale er éi av fleire moglege.

Figur 4 illustrerer oppbygginga av Jeg sykla i time etter time. For å halde figuren enkel har eg abstrahert vekk frå skiljet mellom type og instans. Betydninga til $i$ er illustrert med ei pil frå primærdeltakaren $\mathrm{x}$ til sekundærdeltakaren y. Når ein kombinerer $i$ med time etter time, blir sekundærdeltakaren til $i$ (skravert y) identifisert med betydninga til N1. Når ein vidare kombinerer $i$ time etter time med resten av setninga, Jeg sykla (her enkelt vist med s-boksen), blir primærdeltakaren til $i$ (skravert $\mathrm{x}$ ) identifisert med aktiviteten 'eg sykla'.

Islandske NPN-ar har kasusmarkering av N1, t.d. som i Ég hjólaði klukkustund eftir klukkustund 'Eg sykla time etter time'. N1 står i akkusativ, som generelt er vanleg ved adverbiale substantivfrasar for tid. ${ }^{16}$ Islandske kasus dekkjer endå større bruksområde enn ein preposisjon som $i$, men i prinsippet uttrykkjer ein adverbial kasus ein relasjon av same slag som preposisjonen $\mathrm{i}$ ein modifiserande preposisjonsfrase.

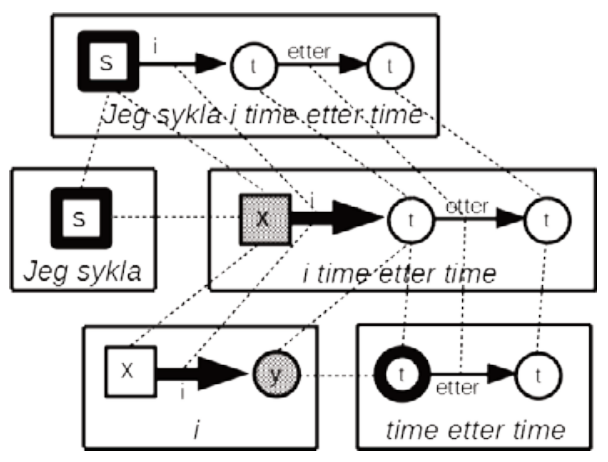

Figur 4. Oppbygginga av Jeg sykla i time etter time

16. N2 står òg i akkusativ, ettersom eftir styrer akkusativ ved tid, men det er ikkje viktig her. 


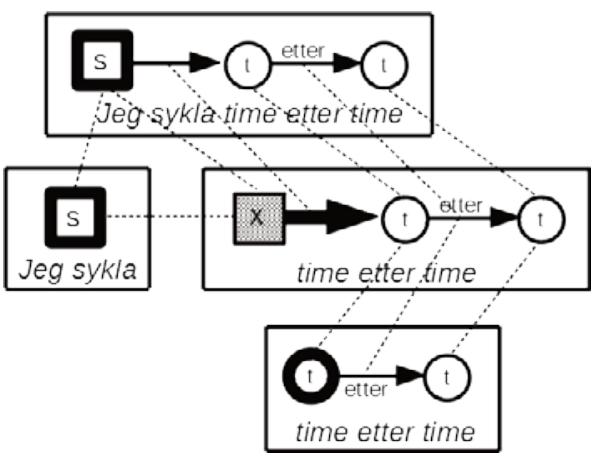

Figur 5. Oppbygginga av Jeg sykla time etter time

I eit språk som norsk der substantiv jamt over ikkje har kasusbøying lenger, har ein ikkje kasusmarkering av den adverbiale relasjonen. Brukar ein då heller ikkje preposisjon, er det fråværet av uttrykk som må tolkast. I ei setning som Jeg sykla time etter time tolkar ein det slik at det er ein temporal relasjon mellom aktiviteten ('eg sykla') og tidsrommet ('time etter time'). Figur 5 viser oppbygginga av semantikken i setninga. Ein liknande relasjon som den som er uttrykt av $i$ i figur 4, blir her tolka inn som det som knyter saman 'eg sykla' (s) og 'time etter time' (t-delen), utan at denne betydninga har noko eige uttrykk. Modifiserande NPN er altså ein eksosentrisk (kjernelaus) konstruksjon.

Modifiserande time etter time har same uttrykk som nominalt time etter time. Dette kan sjåast på som ein syntaktisk parallell til konversjon (nullavleiing) i morfologien, t.d. når verbstammen mur-i MURE ('byggje mur') har same form som (det vi kan anta er) den meir grunnleggande substantivstammen mur-i MUR 'vegg av stein'. På liknande vis som ein

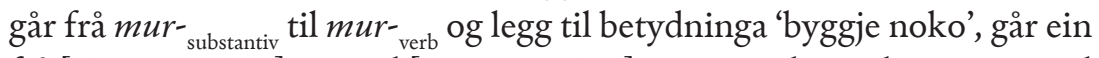
frå [time etter time $]_{\text {nominal }}$ til [time etter time $]_{\text {modifiserar }}$ og legg til ein temporal relasjon. Dette går fram av tilhøvet mellom den nedste boksen i figur 5 og boksen ovanfor.

Sidan ein modifiserande NPN inneber ei slags syntaktisk nullavleiing, er det meir eit teoretisk enn eit empirisk spørsmål om uttrykket «eigentleg» er nominalt eller modifiserande. Dette er prinsipielt ikkje ulikt situasjonen ved modifiserande substantivfrasar som flere timer i Vi sykla flere timer. Det som likevel er spesielt for NPN-ane, er at mange av dei sjeldan eller aldri har nominal funksjon. Det gjeld t.d. arm i arm. Men her kan ein appellere til eit $\varnothing$ konomiprinsipp i den deskriptive gramma- 


\section{TORODd KinN}

tiske modellen (utan å anta noko om kognitiv representasjon): Dersom time etter time i nominal funksjon er ein substantivfrase, er det rimeleg å rekne med at den frasen finst òg når time etter time har modifiserande funksjon. (Det same gjeld flere timer.) Og dersom modifiserande time etter time byggjer på ein substantivfrase, er det rimeleg å rekne med at modifiserande arm i arm òg gjer det. Éin empirisk grunn til å analysere alle norske modifiserande NPN-ar slik, er at tilsvarande islandske uttrykk er kasusmarkerte substantivfrasar. Det verkar ikkje rimeleg å anta at dei norske uttrykka ikkje skal vere substantivfrasar når dei er heilt like dei islandske substantivfrasane - bortsett frå «manglande» kasus.

\section{Modifiserande ledd i NPN}

Den vanlegaste forma for tilleggsledd i norske NPN-konstruksjonar er modifiserande preposisjonsfrasar. Vi skal kort sjå på to nokså ulike typar av slik modifikasjon, illustrerte i (30)-(31) og (32). NPN-ane i (30) og (31) er pseudopartitive konstruksjonar der NPN-sekvensen uttrykkjer målet og substantivfrasen etter høvesvis med og av uttrykkjer arten (sjå Kinn (2001) og Midtbø (2019) om norske pseudopartitivar). Her står modifiseraren til NPN-en som nominal, noko ein kan sjå ved å samanlikne med flere kopper med te eller toddy og flere lag av betydninger. Oppbygginga av ein verbfrase med ein slik NPN som objekt er vist til venstre i figur $6 .{ }^{17}$

(30) mens hun drikker kopp på kopp med te eller toddy (LBK)

(31) Litteraturforskere har avdekket lag på lag av betydninger (LBK)

(32) Det var første gang ofrene sto ansikt til ansikt med de tiltalte (LBK)

Modifiseraren i adverbialet i (32) står ikkje til den nominale delen av NPN-en. Det kan ein konstatere ved å observere at *et ansikt med de tiltalte og liknande ikkje er brukande norsk. Eit uttrykk som stå ansikt til ansikt med de tiltalte kan samanliknast med t.d. ligge parallelt med gata. Sidan modifiseraren ikkje kan knytast til NPN-en som nominal, er det

17. Sjølv om modifiseraren på uttrykkssida står til N2, står han til N1 òg på innhaldssida. Dette kan forklarast ut frå semantikken som det er gjort greie for i avsnitt 2.4, sjå Kinn (under utgiving). 

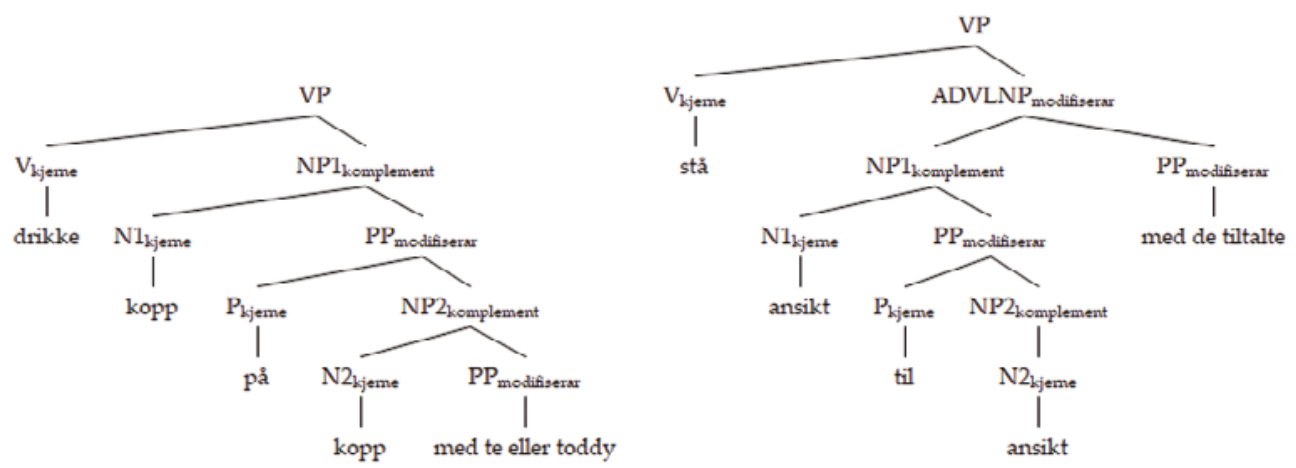

Figur 6. NPN-ar med ulike typar modifikasjon

rimeleg å anta at han er innordna i det eksosentriske modifiserande NPN-nivået. Dette er vist til høgre i figur 6.

\section{Dei einskilde preposisjonane}

Basert på eksemplarfrekvens kan det seiast at det er åtte preposisjonar som førekjem vanleg i NPN-ar; dei utgjer 9210 av totalt 9241 NPN-eksemplar i materialet. Dei kjem i alfabetisk rekkjefølgje her: etter, for, $i$, $m o t$, om, på, til og ved. ${ }^{18}$ Til sist ser vi på NPN-ar med andre preposisjonar som førekjem berre sjeldan, til saman 31 gonger.

\section{1 $\mathrm{N}$ etter $\mathrm{N}$}

Preposisjonen etter har den vanlege betydninga si i $N$ etter $N$; han står for ein relasjon mellom ein primærdeltakar som følgjer ein sekundærdeltakar, i tid eller rørsle. NPN-ar med etter har kjedebetydning, så dei er fleirtalsaktige.

Det er 2486 eksemplar av $N$ etter $N$ i materialet, fordelte på 519 typar (sjå tabell 1). Heile 341 av dei er hapaxar, t.d. karavell etter karavell. Gjennomsnittsfrekvensen for typane (altså type/eksemplar) er 4,8, og hapax/eksemplar er 13,7\%. Det betyr at dette er ein svært produktiv konstruksjon. Konstruksjonen er om lag like ofte brukt modifiserande og

18. Netter $N, N$ for $N$ og $N$ på $N$ har temmeleg like betydningar; dei har kjedebetydning og er ikkje uvanlege i nominal funksjon. Eg samanliknar dei meir detaljert i Kinn (under vurdering). 


\section{TORODd KinN}

nominalt. Men det er mange fleire hapaxar i nominal bruk, som derfor er vesentleg meir produktiv enn modifiserande bruk.

Mellom dei frekvente uttrykka med etter dominerer substantiv for tidsrom: år etter år, dag etter dag, time etter time, kveld etter kveld osv. - og det beslekta gangetter gang. Substantiv for avstand har vi i mil etter mil og kilometer etter kilometer. Runde etter runde har både tid og avstand som sentrale betydningselement. Substantiv for geografiske område finn vi i land etter land, rom etter rom, by etter by. Vi finn substantiv for tekst: side etter side, boketter bok, og det beslekta film etter film. Og eg kan nemne generasjon etter generasjon og plagg etter plagg.

Mellom adverbiala dominerer uttrykk for utstrekning i tid sterkt (33), men lengdeutstrekning er òg vanleg (34). Mange ulike uttrykk for distribusjonsmåte førekjem, som i (35) og (36). Ein kan òg støyte på modifiserande tillegg til substantiv, som i (37).

(33) det voldsomme snøværet som raste dag etter dag (LBK)

(34) Det siste er viktig for å makte å trå mil etter mil med 25 kilo oppakning på sykkelen (LBK)

(35) Med begge hender ... dyttet han meg ut, behendig og smertefullt, støt etter støt (LBK)

(36) Jeg skal ribbe hver eneste fugl, fjær etter fjær - plukk, plukk, plukk, plukk, plukk (LBK)

(37) Etter daglig og iherdig trening måned etter måned overvant han litt etter litt haltingen (LBK)

I nominal bruk er komplement til $i$ den mest frekvente typen (38). Desse står oftast for tid og kan seiast å konkurrere med dei adverbiale uttrykka. Men slike uttrykk er òg komplement til andre preposisjonar, som i (39) og (40):

(38) Viseministre ble sittende som fungerende ministre i måned etter måned (LBK)

(39) På punkt etter punkt ble det klubbet gjennom vedtak som vil koste flesk (LBK)

(40) I tidligere mesterskap har hun grått seg gjennom intervju etter intervju (LBK)

Eksempel på andre nominale funksjonar er objekt (41), subjekt (42), potensielt subjekt (43) og subjektspredikativ (44). 
(41) jeg skalv og drakk mugge etter mugge med vann (LBK)

(42) rektor etter rektor hadde utvist ham og truet med å kaste ham ut (LBK)

(43) Men vi kan ikke godta at det går år etter år uten at det skjer noe (LBK)

(44) Så det ble dag etter dag hvor de satt og drakk te (LBK)

\begin{tabular}{lrrr}
\hline & \multicolumn{3}{c}{ Netter N } \\
\hline & Mod. & Nom. & Alt \\
\hline Eksemplar & 1250 & 1126 & 2486 \\
Typar & 105 & 443 & 519 \\
Hapaxar & 66 & 305 & 341 \\
Eks./type & 11,9 & 2,5 & 4,8 \\
Hapax/eks. & 5,3 & 27,1 & 13,7 \\
\hline
\end{tabular}

\begin{tabular}{lrrr}
\hline & \multicolumn{3}{c}{ Nfor $N$} \\
\hline & Mod. & Nom. & Alt \\
\hline Eksemplar & 1473 & 142 & 1682 \\
Typar & 233 & 75 & 270 \\
Hapaxar & 136 & 51 & 159 \\
Eks./type & 6,3 & 1,9 & 6,2 \\
Hapax/eks. & 9,2 & 35,9 & 9,5 \\
\hline
\end{tabular}

Tabell 1. Frekvensar og produktivitetsmål for $N$ etter $N$ og $N$ for $N$. Mod. = modifiserande bruk. Nom. $=$ nominal bruk. Alt $=$ modifiserande bruk + nominal bruk + uklassifiserte eksemplar. Hapax/eksemplar er uttrykt i prosent.

\section{2 $\mathrm{N}$ for $\mathrm{N}$}

Brukt i NPN-konstruksjonen er for lite semantisk gjennomsiktig. Den vanlegaste betydninga til for i moderne norsk er truleg benefaktiv, men det passar ikkje i NPN-ar med for. Uttrykksmåten er lånt frå tysk N für $N$ (Norsk Ordbok, s.v. IX for A 1 f), og ifølgje Grimm si ordbok har preposisjonen für hatt betydninga 'framfor, før' der (Deutsches Wörterbuch, s.v. für I A 3). Den opphavelege og relevante historiske betydninga er dermed den same som i stå for retten. Preposisjonen står der for ein relasjon der ein primærdeltakar er framfor ein sekundærdeltakar, og overført til tid vil det seie ' $f \varnothing r$ '. Historisk er det altså den konverse relasjonen i høve til etter. I døma vi skal sjå på, har $N$ for $N$ kjedebetydning. (Eg minner om at eg har utelukka uttrykk som øye for øye, som ikkje har det, jf. avsnitt 3.2.)

Det er 1682 eksemplar med $N$ for $N$ i materialet, fordelte på 270 typar, mellom dei 159 hapaxar, t.d. nek for nek (sjå tabell 1). Dette gir ein gjennomsnittleg frekvens for typane på 6,2, og hapax/eksemplar er 9,5\%. Dette er med andre ord òg ein svært produktiv konstruksjon. Her dominerer den modifiserande bruken klart over den nominale, med vel ti gonger så mange eksemplar. Nominal bruk har ein mykje lågare type- 


\section{TORODd KinN}

frekvens, men det er mange hapaxar, noko som gir eit høgt produktivitetsmål på det nominale feltet.

Ser vi på frekvent førekommande uttrykk, finn vi for det første uttrykk med substantiv for rørsleeiningar: skritt for skritt, trinn for trinn, steg for steg. Så er det uttrykk med substantiv for tidsinndeling: dag for dag, år for år, minutt for minutt og fleire. Substantiv for ulike slags små einingar finn vi i uttrykk som bit for bit, punkt for punkt, stykke for stykke, dråpe for dråpe o.a., og eg kan nemne uttrykk med teksteiningar: ord for ord, linje for linje, setning for setning, side for side.

I (45) -(47) er det gitt nokre representative adverbiale døme. Modifiserande bruk i substantivfrase er illustrert i (48).

(45) mens skipet flytter seg centimeter for centimeter (LBK)

(46) Mesteparten av historien ble trykket bit for bit i RAW (LBK)

(47) Lydfilene transkriberes ord for ord og bruk av parafrasering markeres (LBK)

(48) Se også artikkel om Manchester Uniteds resultater sesong for sesong (LBK)

Innanfor den mindre frekvente nominale bruken er det objekt som dominerer, som i (49) og (50), mens subjekt (51) og komplement i preposisjonsfrase (49) er mindre vanleg.

(49) Julekalenderen var et torturkammer hvor han åpnet $\mathbf{d} \varnothing \mathbf{r}$ for $\mathbf{d} \varnothing \mathbf{r}$ (LBK)

(50) Han solgte fra stykke for stykke av garden (LBK)

(51) Potte for potte blir fylt med frø av alle slag (LBK)

(52) Erkeliberalisten går gjennom punkt for punkt, tema for tema (LBK)

\section{$6.3 \mathrm{~N}$ i N}

Den typiske betydninga til $i$ må vel seiast å vere ein relasjon mellom eit innhald og ein behaldar. I $\mathrm{N} i \mathrm{~N}$-uttrykka har preposisjonen ei noko annleis betydning: ein relasjon der ein primærdeltakar er eller kjem i tett kontakt med ein sekundærdeltakar. Slik betydning førekjem ved $i$ elles òg, t.d. i Huset ligger kloss i veien.

NPN-ar med $i$ har dels tvillingbetydning (som vegg $i$ vegg), dels kjedebetydning (som kasti kast). Dette er avhengig av kva som er den naturlege tolkinga av situasjonen: To vegger «møter» kvarandre, mens to kast i ei rørsle følgjer etter kvarandre. 
Det er 1121 eksemplar av uttrykk med $i$ i materialet, fordelte på 27 typar (sjå tabell 2). Det er 15 hapaxar, t.d. kropp $i$ kropp. Dette gir høge gjennomsnittlege frekvensar for typane og låg verdi for hapax/eksemplar. $N i N$ er berre unntaksvis brukt nominalt.

\begin{tabular}{lrrr}
\hline & \multicolumn{3}{c}{$N i N$} \\
\hline & Mod. & Nom. & Alt \\
\hline Eksemplar & 1060 & 7 & 1121 \\
Typar & 21 & 5 & 27 \\
Hapaxar & 14 & 3 & 15 \\
Eks./type & 50,5 & 1,4 & 41,5 \\
Hapax/eks. & 1,3 & 42,9 & 1,3 \\
\hline
\end{tabular}

\begin{tabular}{lrrr}
\hline & \multicolumn{3}{c}{$N$ mot $N$} \\
\hline & Mod. & Nom. & Alt \\
\hline Eksemplar & 206 & 31 & 283 \\
Typar & 61 & 17 & 86 \\
Hapaxar & 37 & 13 & 58 \\
Eks./type & 3,4 & 1,8 & 3,3 \\
Hapax/eks. & 18,0 & 41,9 & 20,5 \\
\hline
\end{tabular}

Tabell 2. Frekvensar og produktivitetsmål for $N i N$ og $N$ mot $N$. Sjå elles tabell 1.

Tre uttrykk er høgfrekvente: hånd i hånd, arm i arm, vegg i vegg. Tre andre er vanlege, men noko mindre frekvente: slag $i$ slag, kast $i$ kast, kant $i$ kant. Saman utgjer desse seks det meste av $i$-materialet. (53)-(57) viser døme. Døme med lågfrekvente uttrykk er gitt i (58) og (59).

(53) De går langsomt arm i arm mellom de lysegrønne bøkene (LBK)

(54) Hånd i hånd gikk de tilbake til bilen uten å snakke (LBK)

(55) slik at harven traff kant i kant med det forrige åkerstykket (LBK)

(56) Bilen gikk kast i kast ned skråningen (LBK)

(57) Hattemakeren holdt til i verkstedet vegg i vegg (LBK)

(58) Hjertet hamret hugg i hugg (LBK)

(59) De fortsetter, gutten tråkk i tråkk tett innpå (LBK)

\section{$6.4 \mathrm{~N} \operatorname{mot} \mathrm{N}$}

Alle NPN-ar med mot har tvillingbetydning. I dei fleste tilfella er betydninga slik at deltakarane møtest og har motsett orientering (rygg mot rygg), delvis slik at dei kjempar mot kvarandre (mann mot mann). Ein annleis betydningsvariant har å gjere med at den eine deltakaren blir utveksla mot den andre (vare mot vare).

Her er det 283 eksemplar fordelte på 86 typar, av dei 58 hapaxar, t.d. horn mot horn (sjå tabell 2). Dette gir ein snittfrekvens for typane på 3,3 


\section{TORODd KinN}

og eit temmeleg høgt tal for hapax/eksemplar: $20,5 \%$. Konstruksjonen er klart oftast modifiserande, men nominal bruk førekjem ein del.

Det mest frekvente uttrykket er mann mot mann. Ingen andre med substantiv for menneske er frekvente i materialet, men dei førekjem: kvinne mot kvinne, bror mot bror osv., òg slike med substantiv for grupper, som klasse mot klasse. Eit større spektrum finn ein med substantiv for kroppsdelar, som rygg mot rygg, kinn mot kinn og skulder mot skulder, og for delar av f.eks. køyretøy, som front mot front. To nokså frekvente uttrykk med abstrakt substantiv er ord motord og påstand motpåstand. Ein kan kanskje sjå på dette som abstrakte instrument, og då kan ein nemne lågfrekvente uttrykk som $\varnothing k s$ mot $\varnothing k s$ og stokk mot stokk med konkret substantiv.

NPN-ar med mot er i all hovudsak modifiserande, som illustrert i (60)-(62). Men det er òg eit visst innslag av nominal bruk, framfor alt predikativ med ord mot ord og påstand mot påstand, som i (63).

(60) mens russiske og finske styrker fremdeles sloss mann mot mann i sentrum (LBK)

(61) De la seg rygg mot rygg og ble liggende lenge våkne (LBK)

(62) Inntrengerne ... viste seg ... farlige i kamp mann mot mann (LBK)

(63) Men i konflikten mellom Valla og Yssen var det fremdeles ord mot ord (LBK)

(64) viser eit døme der mot har utvekslingsbetydning. Det er typisk substantiv som ytelse, vare og tjeneste som er brukte på denne måten, og ingen slike uttrykk er frekvente.

(64) For tjenester som gjelder oppdrett ... vil det gjennomgående foreligge ytelse mot ytelse (LBK)

\section{$6.5 \mathrm{~N}$ om $\mathrm{N}$}

Materialet inneheld 789 eksemplar av Nom N (sjå tabell 3). 787 av dei er side om side, og så er det to hapaxar. Det gir ein svært høg gjennomsnittleg frekvens for typane, og hapax/eksemplar gir eit svært lågt produktivitetsmål. Preposisjonen om betyr typisk 'rundt', 'som handlar om ...', men slik betydning er det vanskeleg å sjå i side om side. Dette uttrykket har elles konkurranse av side ved side.

Side om side er illustrert i (65). Ein av hapaxane er vist i (66). 
(65) Bibelen ser frem til en tid da løven og lammet skal ligge side om side (LBK)

(66) Rundt henne bølga de, par om par, mest var de ukjente for Anna (LBK)

\begin{tabular}{lrrr}
\hline & \multicolumn{3}{c}{ Nom N } \\
\hline & Mod. & Nom. & Alt \\
\hline Eksemplar & 768 & 1 & 789 \\
Typar & 3 & 1 & 3 \\
Hapaxar & 2 & 1 & 2 \\
Eks./type & 256,0 & 1,0 & 263,0 \\
Hapax/eks. & 0,3 & 100,0 & 0,3 \\
\hline
\end{tabular}

\begin{tabular}{lrrr}
\hline & \multicolumn{3}{c}{$N$ på } \\
\hline & Mod. & Nom. & Alt \\
\hline Eksemplar & 1114 & 449 & 1672 \\
Typar & 17 & 192 & 241 \\
Hapaxar & 11 & 136 & 164 \\
Eks./type & 65,5 & 2,3 & 6,9 \\
Hapax/eks. & 1,0 & 30,3 & 9,8 \\
\hline
\end{tabular}

Tabell 3. Frekvensar og produktivitetsmål for $N$ om $N$ og $N$ på $N$. Sjå elles tabell 1.

\section{$6.6 \mathrm{~N}$ på $\mathrm{N}$}

Betydninga til preposisjonen $p a ̊$ strekkjer seg frå den grunnleggande der ein primærdeltakar er eller hamnar oppå ein sekundærdeltakar, til ei meir abstrakt betydning av at primærdeltakaren kjem i tillegg til sekundærdeltakaren. NPN-ar med på har kjedebetydning.

Materialet inneheld 1672 eksemplar av uttrykk med på, fordelte på 241 typar (sjå tabell 3). Det er 164 hapaxar, t.d. søknad på søknad. Snittfrekvensen for typane er 6,9, og hapax/eksemplar er 9,8 \%, så dette er ein klart produktiv konstruksjon. Modifiserande bruk dominerer, men dette kjem i hovudsak av at gang på gang har heile 1061 eksemplar. For nominal bruk er snittfrekvensen for typane lågare og hapax/eksemplar høgre.

Langt over helvta av eksemplara er altså gang på gang. Andre vanlege uttrykk er lag på lag, stein på stein (ofte metaforisk), rad på rad, rekke på rekke, meter på meter, hylle på hylle, side på side.

Gangpå gang er gjennomført modifiserande (67), inkl. nokre døme på tillegg til substantiv (68). (69) og (70) viser nokre andre adverbiale døme.

(67) Det at hun har gått på trynet gang på gang, betyr ikke at alle andre vil gjøre det (LBK)

(68) at det tydet mindre bra med tilbaketrekning gang på gang (LBK) 


\section{Torodd KinN}

(69) Det var så bratt her at alle hagene var anlagt lag på lag i terrasser (LBK)

(70) Altså en som dyrker det som alt er der, som bygger videre sten på sten (LBK)

I (71)-(75) illustrerer eg nominal bruk, høvesvis objekt, komplement til preposisjon, subjekt, potensielt subjekt og subjektspredikativ.

(71) Sammen slengte vi kasse på kasse over på tralla (LBK)

(72) Med dette unnlot man i tiår på tiår å ta et oppgjør (LBK)

(73) Stjerneskudd på stjerneskudd river opp himmelens mørkeblå duk (LBK)

(74) Utenpå hadde det vokst skall på skall av visdom og styrke (LBK)

(75) Alt jeg kan se er bunke på bunke med sider (LBK)

\section{$6.7 \mathrm{~N}$ til $\mathrm{N}$}

$N$ til $N$-uttrykk viser normalt til situasjonar der eitt menneske (primærdeltakar) vender seg mot eit anna (sekundærdeltakar) i noka form for verbal eller ikkje-verbal kommunikasjon. Substantiva som inngår, står for kroppsdelar, personar eller menneskesinn. Uttrykka har tvillingbetydning.

Materialet inneheld 920 eksemplar av $N$ til $N$ (sjå tabell 4). Dei er fordelte på berre 22 typar, og av dei er helvta hapaxar, t.d. sjel til sjel. Det gir høg gjennomsnittleg frekvens for typane og låg verdi for hapax/eksemplar. Modifiserande bruk er det normale, men det er nokre nominale døme.

Det klart mest frekvente uttrykket er ansikt til ansikt. Elles er det berre øye til øye, åsyn til åsyn og mann til mann som går att med ein viss frekvens. I (76)-(77) er det døme på adverbial, (78) illustrerer modifiserar til substantiv. (79) viser nominal bruk som komplement til preposisjon; dette er eit metonymisk uttrykk for 'kommunikasjon ansikt til ansikt' (sjå avsnitt 4.2).

(76) nå som de snakket så oppriktig sammen, nabo til nabo, mann til mann (LBK)

(77) Men minneverdig for hvem? For ham, som sto øye til øye med det minneverdige syn? (LBK)

(78) Med andre ord kan fraværende svar ansikt til ansikt bli oppfattet som betydningsfulle kommunikative signaler (LBK)

(79) at tilbakekoplingssignaler ikke i samme grad brukes her som i ansikt til ansikt (LBK) 
NORSKE NPN-KONSTRUKSJONAR

\begin{tabular}{lrrr}
\hline & \multicolumn{3}{c}{ N til N } \\
\hline & Mod & Nom. & Alt \\
\hline Eksemplar & 888 & 25 & 920 \\
Typar & 18 & 6 & 22 \\
Hapaxar & 10 & 3 & 11 \\
Eks./type & 49,3 & 4,2 & 41,9 \\
Hapax/eks. & 1,1 & 12,0 & 1,2 \\
\hline
\end{tabular}

\begin{tabular}{lrrr}
\hline & \multicolumn{3}{c}{ Nved N } \\
\hline & Mod & Nom. & Alt \\
\hline Eksemplar & 240 & 5 & 257 \\
Typar & 10 & 5 & 14 \\
Hapaxar & 8 & 5 & 11 \\
Eks./type & 24,0 & 1,0 & 18,4 \\
Hapax/eks. & 3,3 & 100,0 & 4,3 \\
\hline
\end{tabular}

Tabell 4. Frekvensar og produktivitetsmål for $N$ til $N$ og $N$ ved $N$. Sjå elles tabell 1.

\section{$6.8 \mathrm{~N}$ ved $\mathrm{N}$}

Betydninga til ved i $N$ ved $N$ er den vanlege, der ein primærdeltakar er nær inntil ein sekundærdeltakar. Materialet er på 257 eksemplar fordelte på 14 typar (sjå tabell 4). Det er 11 hapaxar; døme på det er gitt i (82) og (83). Dette gir forholdsvis høg snittfrekvens for typane og nokså låg verdi for hapax/eksemplar, altså låg produktivitet. Så å seie alle døma er modifiserande.

To uttrykk utgjer nesten heile materialet: side ved side og skulder ved skulder. Desse er illustrerte i (8o) og (81). Side ved side betyr om lag det same som det mindre gjennomsiktige side om side. Eit nominalt d $\varnothing \mathrm{me}$ med subjekt er vist i (82), og (83) har eit predikativ.

(80) Side ved side gikk de opp Universitetsgata og hjem (LBK)

(81) men jeg har alltid drømt om å stå skulder ved skulder med den legendariske Beranabus i kamp (LBK)

(82) En nyfødt pike og en mor og rosenstokk ved rosenstokk på samme underlige jord er mere enn mirakel nok (LBK)

(83) og der det i 1775 var stein på stein og myr ved myr, var det ... en mannsalder senere et frodig jordbrukslandskap (LBK)

\subsection{Andre preposisjonar}

Utover NPN-ar med dei åtte preposisjonane som er presenterte i dei $f_{\varnothing-}$ regåande avsnitta, førekjem det uttrykk med andre preposisjonar, men berre sjeldan. I materialet er det i alt 31 eksemplar fordelte på 24 typar: over (12 eksemplar, 9 typar), bak (10, 8), som (3, 2), innenfor $(2,1)$, gjennom 


\section{TORODd KinN}

(1), inni (1), inntil (1), oppå (1). Nokre døme er gitt i (84)-(89). Haukover hauk som i (85) er eit metaforisk uttrykk. Desse døma kan vel seiast å vise at NPN-konstruksjonen sjølv på det mest skjematiske nivået har eit visst produktivitetspotensial.

(84) Blånene lå rygg bak rygg inntil himmelens $r ø \mathrm{dfa}[\mathrm{r}]$ ger blandet seg med grått og svart (LBK)

(85) Hvis Justisdepartementet blander seg inn, blir det hauk over hauk (LBK)

(86) Tankene mine siver gjennom tankene lik fall gjennom fall bak det som fortsetter (LBK)

(87) [Installasjonen] består av rom innenfor rom som et kinesisk eske-system (LBK)

(88) Slik lå gardene til, hage inntil hage (LBK)

(89) Der alt de har berørt spilles igjen, omkodet og sammensurret, bilde oppå bilde, og aldri kommer til ro eller rekkefølge (LBK)

\section{Oppsummering og avslutning}

I innleiinga peikte eg på at det er lite som er kjent om norske NPN-konstruksjonar, og eg stilte tre spørsmål:

- Kva preposisjonar er brukte i norske NPN-konstruksjonar?

- I kva grad er NPN-konstruksjonane høvesvis modifiserande og nominale?

- Kor produktive er NPN-konstruksjonane?

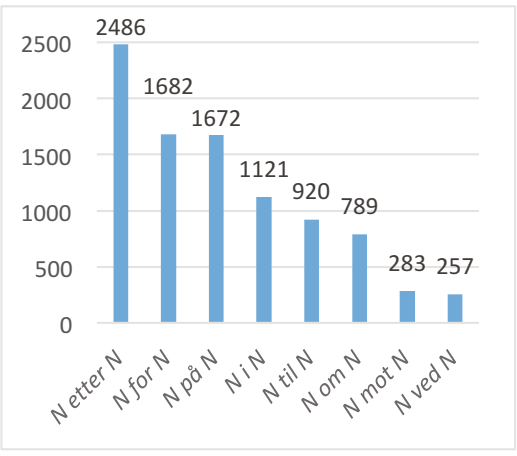

Figur 7. Eksemplarfrekvensar

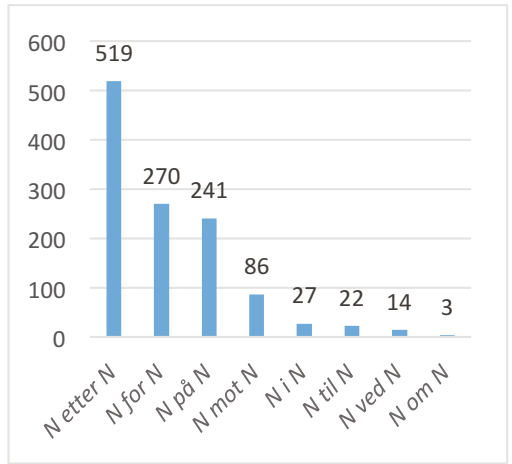

Figur 8. Typefrekvensar 
Ei stor undersøking i Leksikografisk bokmålskorpus har gitt grunnlag for å svare på desse spфrsmåla. Eit innleiande materiale med over 14250 treff på NPN-sekvensar blei skore ned til $9241 \mathrm{~d} \varnothing$ me på NPN-konstruksjonar. 9210 av dei inneheldt éin av åtte frekvente preposisjonar: etter, for, i, mot, om, på, til og ved. Eksemplar- og typefrekvensane deira er viste i høvesvis figur 7 og figur 8 . $N$ etter $N, N$ for $N$ og $N$ på $N$ toppar begge statistikkane.

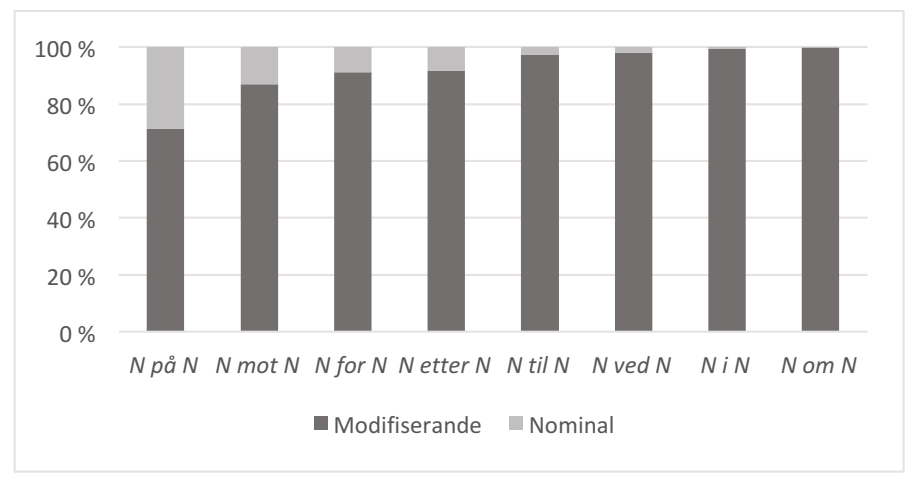

Figur 9. Modifiserande og nominal funksjon ved NPN-konstruksjonar

Norske NPN-konstruksjonar er i hovudsak modifiserande, men ved nokre preposisjonar er det eit monaleg innslag av nominal funksjon. Dette er vist i figur 9, der ikkje-klassifiserte døme er haldne utanfor. Mest nominal funksjon finn ein ved $N$ på $N$, og om ein ser vekk frå det høgfrekvente gang på gang, er nominal funksjon meir frekvent enn modifiserande funksjon her. Det er òg ein del nominal bruk ved $N$ mot $N, N$ for $N$ og $N$ etter $N$. ( $N$ mot $N$ skil seg her frå dei andre ved at det meste av den nominale bruken er predikativ.)

Figur 10 framstiller produktiviteten til NPN-konstruksjonane. Eg har lagt inn tal for modifiserande og nominal bruk og tal der alle døme inkl. dei syntaktisk uklassifiserte er med. Kategoriar med færre enn 25 eksemplar er utelatne. Produktivitet viser seg dels ved høg typefrekvens (oppover), dels ved at hapaxfrekvens delt på eksemplarfrekvens gir eit stort tal (mot høgre). 


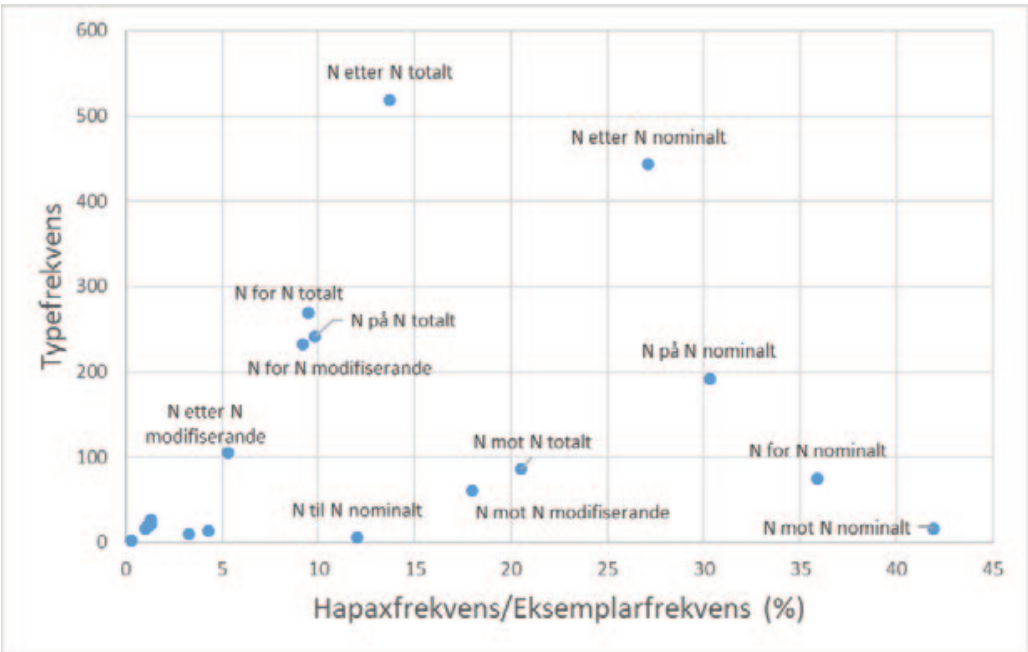

Figur 10. Produktiviteten til NPN-konstruksjonane

Det er konstruksjonane med etter, på og for som står ut som dei mest produktive: $N$ etter $N$ (totalt og nominalt, men i mindre grad modifiserande), $N$ på $N$ (nominalt og totalt, men ikkje modifiserande) og $N$ for $N$ (totalt og modifiserande, men i mindre grad nominalt). Av NPN-ar med andre preposisjonar er det ingen med typefrekvens over 100. Men $N$ mot $N$ (nominalt, totalt, modifiserande) har forholdsvis høge verdiar for hapax/eksemplar, og $N$ til $N$ (nominalt) skil seg òg noko ut frå dei resterande (konstruksjonane utan merkelappar nede til venstre).

Med (meir enn) 9241 eksemplar fordelte på 1206 typar i Leksikografisk bokmålskorpus er det ingen tvil om at NPN-konstruksjonane utgjer ein ikkje liten del av det norske konstruksjonsforrådet. Mange uttrykk er svært etablerte og frekvente, som år etter år, skritt for skritt, hånd i hånd, kinn mot kinn, side om side, gang på gang, ansikt til ansikt og skulder ved skulder. Men materialet her omfattar òg heile 778 hapaxar, noko som tydeleg demonstrerer høg produktivitet ved NPN-konstruksjonen i norsk, og særleg ved variantane $N$ etter $N, N$ på $N$ og $N$ for $N$.

\section{Litteraturliste}

Barlow, Michael \& Suzanne Kemmer (red.). 200o. Usage based models of language. Stanford, California: CSLI Publications. 
Bauer, Laurie. 2001. Morphological productivity. Cambridge: Cambridge University Press.

Beck, Sigrid \& Arnim von Stechow. 2005. Dog after dog revisited. I: Proceedings of the Sinn und Bedeutung 10 (ZAS Papers in Linguistics 44), red. Christian Evert \& Cornelia Endriss, 43-54.

- 2007. Pluractional adverbials. Journal of Semantics 24, 215-254.

Boberg, Per. 2009. Word by word, phrase by phrase, sentence by sentence: $A$ corpus-based study of the $\mathrm{N}_{1}$ by $\mathrm{N}_{1}$ construction. Masteroppgåve, Växjö universitet.

Borthen, Kaja. 2003. Norwegian bare singulars. Doktoravhandling, Noregs teknisk-naturvitskaplege universitet.

Haik, Isabelle. 2013. Symmetric structures. Corela 11. http://corela.revues.org/2875 (bes $\varnothing \mathrm{kt}$ 12.12.2020).

Haugen, Tor Arne \& Hans-Olav Enger. 2019. The semantics of Scandinavian pancake constructions. Linguistics 57, 531-575.

Hoffmann, Thomas \& Graeme Trousdale (red.). 2013. The Oxford Handbook of Construction Grammar. Oxford: Oxford University Press.

Jackendoff, Ray. 2008. 'Construction after construction' and its theoretical challenges. Language 84, 8-28.

Kinn, Torodd. 2001. Pseudopartitives in Norwegian. Doktoravhandling, Universitetet i Bergen.

- Under utgiving. Regular and compositional aspects of NPN constructions. Journal of Linguistics.

—. Under vurdering. År etter år, skritt for skritt og lag på lag: tre NPNkonstruksjonar.

Knudsen, Rune Lain \& Ruth Vatvedt Fjeld. 2013. LBK 2013: A balanced, annotated national corpus for Norwegian Bokmål. Proceedings of the workshop on lexical semantic resources for NLP at NODALIDA 2013; May 22-24; 2013; Oslo; Norway. NEALT Proceedings Series 19, 12-20. https://www.ep.liu.se/konferensartikel.aspx?series =\&issue $=88 \&$ Article $\_\mathrm{No}=3$ (bes $\varnothing \mathrm{kt}$ 12.12.2020).

Langacker, Ronald W. 1987. Foundations of Cognitive Grammar, bd. 1: Theoretical prerequisites. Stanford, California: Stanford University Press.

- 1991. Foundations of Cognitive Grammar, bd. 2: Descriptive application. Stanford, California: Stanford University Press.

-1999. Virtual reality. Studies in the Linguistic Sciences 29, 77-103. 
-2005. Dynamicity, fictivity, and scanning: The imaginative basis of logic and linguistic meaning. I: Grounding cognition: The role of perception and action in memory, language and thinking, red. Diane Pecher \& Rolf A. Zwaan, 164-197. Cambridge: Cambridge University Press. Lindquist, Hans \& Magnus Levin. 2003. The grammatical properties of recurrent phrases with body-part nouns: The $N_{1}$ to $N_{1}$ pattern. I: Exploring the lexis-grammar interface, red. Ute Römer \& Rainer Schulze, 171-188. Amsterdam: John Benjamins.

Matsuyama, Tetsuya. 2004. The $N$ after $N$ construction: A constructional idiom. English Linguistics 21, 55-84.

Midtb $\varnothing$, Elise. 2019. "En smule konsentrasjon", «den siste skvetten med kaffe» og "haugevis av spørsmål». En undersøkelse av grammatisk og semantisk variasjon ipseudopartitive konstruksjonerpå norsk. Masteroppgåve, Universitetet i Bergen.

Poß, Michaela. 2007. Structural versus constructional semantics: The case of Dutch NPN. Leiden Working Papers in Linguistics 4, 21-39.

- 2010. Under construction: Cognitive and computational aspects of extended lexical units. Utrecht: LOT Publications.

Pskit, Wiktor. 2012. The English NPN forms: Words or constructions? I: Exploring language through contrast, red. Waldemar Skrzypczak, Tomasz Fojt \& Sławomir Wacewicz, 126-144. Newcastle upon Tyne: Cambridge Scholars.

- 2015. The categorial status and internal structure of NPN forms in English and Polish. I: Within language, beyond theories, bd. 1: Studies in theoretical linguistics, red. Anna Bondaruk \& Anna Prażmowska, 27-42. Newcastle upon Tyne: Cambridge Scholars.

- 2017. Linguistic and philosophical approaches to NPN structures.

I: Topics in syntax and semantics: Linguistic and philosophical perspectives, red. Wiktor Pskit, 93-110. Lodz: Wydawnictwo Uniwersytetu Łódzkiego.

Roch, Claudia, Katja Keßelmeier \& Antje Müller. 2010. Productivity of NPN sequences in German, English, French, and Spanish. I: Semantic approaches in natural language processing. Proceedings of the Conference on Natural Language Processing 2010, red. Manfred Pinkal, Ines Rehbein, Sabine Schulte im Walde \& Angelika Storrer, 157-161. Saarbrücken: Universaar.

Rosén, Victoria \& Kaja Borthen. 2017. Norwegian bare singulars revisited. I: The very model of a modern linguist - in honor of Helge Dyvik 
(Bergen Language and Linguistics Studies (BeLLS) 8), red. Victoria Rosén \& Koenraad De Smedt, 220-240. Bergen: Universitetet i Bergen. https://bells.uib.no/index.php/bells/article/view/1330/1216 (bes $\varnothing \mathrm{kt}$ 12.12.2020).

Stvan, Laurel Smith. 2007. The functional range of bare singular count nouns in English. I: Nominal determination: Typology, context constraints, and historical emergence, red. Elisabeth Stark, Elisabeth Leiss \& Werner Abraham, 171-187. Amsterdam: John Benjamins.

Swart, Henriëtte de \& Joost Zwarts. 2007. Less form - more meaning: Why bare singular nouns are special. Lingua 119, 280-295.

Travis, Lisa deMena. 2001. The syntax of reduplication. Proceedings of the North East Linguistic Society (NELS) 31, 455-469.

- 2003. Reduplication feeding syntactic movement. I: Proceedings of the 2003 Canadian Linguistic Association Annual Conference, red. Sophie Burelle \& Stanca Somesfalean, 236-247. Montreal: Université du Québec à Montréal.

Ziem, Alexander. 2018. Tag für Tag Arbeit über Arbeit. Konstruktionsgrammatische Zugänge zu Reduplikationsstrukturen im Deutschen. I: Sprachliche Verfestigung: Wortverbindungen, Muster, Phrasem-Konstruktionen, red. Kathrin Steyer, 25-48. Tübingen: Narr Francke Attempto.

\section{Abstract}

NPN constructions are made up of an indefinite singular count noun followed by a preposition followed by the same noun (e.g. eye to eye and day after day), sometimes followed by a modifier (e.g. crate upon crate of bottles, face to face with the enemy). There are a few studies of such constructions, notably of English, but hardly any of corresponding Norwegian constructions. The article first accounts for some theoretical aspects of the syntax and semantics of NPN constructions. This is followed by an empirical study based on a large data set retrieved from the Lexicographic Corpus of Norwegian Bokmål. Modifying (mostly adverbial) and nominal syntactic functions of NPN constructions are mapped and documented. Further, the productivity of NPNs with eight different prepositions is studied: etter 'after', for 'by' (lit. 'for'), $i$ 'in', mot 'against', om 'by' (lit. 'about'), på '(up)on', til 'to', ved 'by, next to'. Some prepositions 


\section{ToRodd KinN}

are mostly found in modifying NPNs, while others are also common in nominal functions. NPNs with different prepositions vary greatly with respect to productivity. Constructions with etter, på, for, and mot are the most productive, while those with ved and especially om, til, and $i$ exhibit low degrees of productivity.

Torodd Kinn

Universitetet i Bergen

Institutt for lingvistiske, litterære og estetiske studium

Postboks 7805

NO-5020 Bergen

torodd.kinn@uib.no 